\title{
Characteristics of two basolateral potassium channel populations in human colonic crypts
}

\author{
R B Lomax, G Warhurst, G I Sandle
}

\begin{abstract}
The basolateral membrane of human colonic crypt cells contains $\mathrm{Ca}^{2+}$ and cAMP activated, $\mathrm{Ba}^{2+}$ blockable, low conductance (23 pS) $\mathrm{K}^{+}$channels, which probably play an important part in intestinal $\mathrm{Cl}^{-}$secretion. This study has defined more clearly the basolateral $\mathrm{K}^{+}$ conductive properties of human colonic crypts using patch clamp recording techniques. High conductance $(138 \mathrm{pS}) \mathrm{K}^{+}$ channels were seen in $25 \%$ of patches (one or two channels per patch), and significantly inhibited by the addition of $5 \mathrm{mM}$ $\mathrm{Ba}^{2+}, 1 \mathrm{mM}$ quinidine or $20 \mathrm{mM}$ tetraethylammonium chloride (TEA) to the cytosolic side of excised inside-out patches, whereas $1 \mathrm{mM}$ diphenylamine-2carboxylic acid (DPC) had no effect. In contrast, clusters of the $23 \mathrm{pS} \mathrm{K} \mathrm{K}^{+}$channel (two to six channels per patch) were present in $>75 \%$ of patches, and channel activity was inhibited by quinidine and DPC, but not by TEA. Activity of the $138 \mathrm{pS} \mathrm{K}^{+}$channel in inside-out patches was abolished almost completely by removal of bath $\mathrm{Ca}^{2+}$, but in contrast with its effect on the $23 \mathrm{pS} \mathrm{K} \mathrm{K}^{+}$channel, addition of $0.1 \mathrm{mM}$ carbachol had no effect on the $138 \mathrm{pS} \mathrm{K}^{+}$channel in cell attached patches. It is concluded that human colonic crypt cells possess two discrete basolateral $\mathbf{K}^{+}$channel populations, which can be distinguished by their responses to $\mathrm{K}^{+}$channel blockers, and their different sensitivities to changes in intracellular $\mathrm{Ca}^{2+}$ concentration.

(Gut 1996; 38: 243-247)
\end{abstract}

Keywords: human colon, crypt, potassium channel, basolateral membrane, patch clamp.

Secretion of $\mathrm{Cl}^{-}$and water is stimulated in the mucosal crypts of both the small intestine and colon by a range of infective and neurohumoral agents. ${ }^{1}$ Previous studies in a human colonic epithelial cell line $\left(\mathrm{T}_{84}\right)$ have shown that basolateral $\mathrm{K}^{+}$channels are activated during the stimulation of electrogenic $\mathrm{Cl}^{-}$secretion by $\mathrm{Ca}^{2+}$ mediated agonists. ${ }^{2-4}$ Basolateral $\mathrm{K}^{+}$ channels seem to play a critical part in the $\mathrm{Cl}^{-}$secretory process by facilitating the recycling of $\mathrm{K}^{+}$across the membrane to the $\mathrm{Na}^{+}-\mathrm{K}^{+}-2 \mathrm{Cl}^{-}$cotransporter and $\mathrm{Na}^{+}-\mathrm{K}^{+}-$ ATPase, thereby maintaining the electrochemical driving force for apical $\mathrm{Cl}^{-}$exit into the intestinal lumen. ${ }^{5}$

We have recently identified a $\mathrm{Ca}^{2+}$ and cAMP activated, $\mathrm{Ba}^{2+}$ sensitive low conductance (23 pS) $\mathrm{K}^{+}$channel in the basolateral membrane of human colonic crypt cells. ${ }^{6}$ Here, we describe some of the properties of a high conductance basolateral $\mathrm{K}^{+}$ channel, which is also present in human colonic crypts, and compare the responses of the two types of $\mathrm{K}^{+}$channel with known $\mathrm{K}^{+}$ channel blockers.

\section{Methods}

After obtaining written consent, crypts were isolated from healthy mucosa at least $5 \mathrm{~cm}$ from 16 resected carcinomas of the sigmoid colon, or from four to six mucosal biopsy specimens removed from the sigmoid colon during colonoscopic evaluation of 12 patients with the irritable bowel syndrome. Removal of tissue for these studies was approved by the ethics committee of Salford Health Authority. Pieces of mucosa $\left(1 \mathrm{~cm}^{2}\right)$ or mucosal biopsy specimens were washed with ice cold $0.9 \% \mathrm{NaCl}$, and incubated with gentle stirring for 40 minutes at $0-4^{\circ} \mathrm{C}$ in a $\mathrm{Ca}^{2+}$ free solution containing $(\mathrm{mM})$ : $\mathrm{Na}^{+} 112 ; \mathrm{K}^{+}$5; $\mathrm{Cl}^{-}$117; dithiothreitol 3; EDTA 30; and 4-(2-hydroxyethyl-1-piperazine ethanesulphonic acid (HEPES) 20, titrated to $\mathrm{pH} 7 \cdot 1$ with TRIS(hydroxymethyl)aminomethane (TRIS). Mucosae were transferred to an ice cold solution containing $(\mathrm{mM}): \mathrm{Na}^{+} 140$; $\mathrm{K}^{+} 4.5 ; \mathrm{Cl}^{-} 149 \cdot 3 ; \mathrm{Mg}^{2+} 1 \cdot 2 ; \mathrm{Ca}^{2+} 1.2 ; \mathrm{D}-$ glucose 10; and HEPES 10 , titrated to $\mathrm{pH} 7 \cdot 4$ with $\mathrm{NaOH}$, and shaken to release intact crypts, which were collected by centrifugation ( $50 \mathrm{~g}$ for 2 minutes) and kept at $4^{\circ} \mathrm{C}$. Crypts were attached to polyethylenimine coated plastic coverslips placed in a $1.5 \mathrm{ml}$ Perspex chamber, visualised with an inverted microscope with Hoffman modulated optics $(\times 400)$, and pretreated for 30 minutes with $0.1 \mathrm{mM}$ dibutyryl cAMP (a membrane permeant analogue of cAMP) to stimulate $\mathrm{Cl}^{-}$secretion. Single channel recordings were obtained from basolateral membrane patches of cells in the middle third of the crypts in cell attached and excised inside-out configurations. ${ }^{7}$ Experiments were done at $20-22^{\circ} \mathrm{C}$, and crypts were clearly defined for up to five hours.

The bath solution contained $(\mathrm{mM}): \mathrm{Na}^{+}$ $140 ; \mathrm{K}^{+} 4.5 ; \mathrm{Cl}^{-} 149 ; \mathrm{Ca}^{2+} 1 \cdot 2 ; \mathrm{Mg}^{2+} 1 \cdot 2$; D-glucose 10; and HEPES 10 , titrated to $\mathrm{pH}$ $7 \cdot 4$ with $\mathrm{NaOH}$. The pipette solution contained $(\mathrm{mM}): \mathrm{K}^{+} 145 ; \mathrm{Cl}^{-} 149 ; \mathrm{Ca}^{2+} 1 \cdot 2$; $\mathrm{Mg}^{2+} 1 \cdot 2$; D-glucose 10 ; and HEPES 10 , titrated to $\mathrm{pH} 7 \cdot 4$ with $\mathrm{KOH}$. The effects of classic $\mathrm{K}^{+}$channel blockers on channel activity in inside-out patches were studied by adding each blocker to the bath solution (final concentrations (mM): $\mathrm{Ba}^{2+} 5$; quinidine 1 ; tetraethylammonium chloride (TEA) 20). The

\author{
Correspondence to: \\ Dr G I Sandle, Department \\ of Medicine, Hope
Salford M6 8HD. \\ Accepted for publication \\ 9 August 1995 \\ Molecular Physiology \\ Group, Department of \\ of Manchester), Hope \\ Hospital, Salford \\ R B Lomax
}


effects of adding $1 \mathrm{mM}$ diphenylamine-2-carboxylic acid (DPC) to the bath were also studied in inside-out patches. Although DPC is established as a $\mathrm{Cl}^{-}$channel blocker, ${ }^{89}$ it blocks non-selective cation channels in pancreatic acinar cells and renal proximal tubular cells, ${ }^{1011}$ and both inward rectifying $\mathrm{K}^{+}$ channels and non-selective cation channels in the basolateral membrane of turtle colonic epithelium. ${ }^{12}$ The effect of $\mathrm{Ca}^{2+}$ removal on channel activity was studied in inside-out patches by replacing the $\mathrm{Ca}^{2+}$-containing solution with an otherwise identical but $\mathrm{CaCl}_{2}$ free solution containing $2 \mathrm{mM}$ ethylene glycol-bis( $\beta$-aminoethyl ether) $\mathbf{N}, \mathbf{N}, \mathbf{N}^{\prime}, \mathbf{N}^{\prime}$-tetraacetic acid (EGTA).

Unitary currents were recorded with a patch clamp amplifier (List Electronics model EPC-7, Darmstadt, Germany) over a range of command voltages, and referenced to the interior of the patch pipette (that is, the pipette was ground). Currents were stored on video tape after pulse code modulation (Sony model PCM 701ES, Japan). Stored currents were low pass filtered ( $-3 \mathrm{~dB}, 4$-pole Butterworth) and loaded into computer memory (Elonex model PC-450) via a Labmaster TL1 interface and TM40 A/D converter (Axon Instruments, Foster City, CA, USA). All currents were filtered at $750 \mathrm{~Hz}$ and loaded using a sampling frequency of $2.5 \mathrm{kHz}$. Current-voltage $\left(\mathrm{I}-\mathrm{V}_{\text {com }}\right)$ relations were constructed by plotting the unitary current (equal to the difference between the open and closed channel currents) at each value of $\mathrm{V}_{\text {com }}$. The Goldman-Hodgkin-Katz $(\mathrm{GHK})$ current and voltage equations ${ }^{13}{ }^{14}$ were used to calculate $\mathrm{K}^{+}: \mathrm{Na}^{+}$permeability $\left(\mathrm{P}_{\mathrm{K}}: \mathrm{P}_{\mathrm{Na}}\right)$ ratios and reversal potentials $\left(\mathrm{E}_{\mathrm{rev}}\right)$ respectively.

Single channel open probability was determined using an analysis program written in Quick Basic 4.0 (Microsoft, USA). A transition between the fully closed and fully open current levels occurred when the current crossed a threshold set midway between these two states. Single channel open probability $\left(\mathrm{p}_{\mathrm{o}}\right)$ was calculated as:

$$
\mathrm{p}_{\mathrm{o}}=\left(\Sigma \mathrm{nt}_{\mathrm{n}}\right) / \mathrm{N}
$$

where $\mathrm{N}$ is the maximum number of channels seen to be open simultaneously during the recording (lasting $30 \mathrm{~s}$ ) obtained under a specific set of experimental conditions, $n$ represents the state of the channels $(0$, closed; 1 , one channel open, etc), and $t_{n}$ is the time spent in state $\mathrm{n}$. In practice, $\mathrm{N}$ was the maximum number of channels seen to be open simultaneously during the entire lifetime of the membrane patch, which was monitored continuously using an oscilloscope and checked off line by displaying periods of maximal channel activity on a variable speed strip chart recorder (Gould Electronics model 220, Hainault, Ilford, Essex). In theory, the number of channels per patch should have been indicated by the number of Gaussian peaks on the channel current amplitude histogram generated by the single channel analysis program. However, this method tended to underestimate the number of channels per patch. Thus, with patches containing two high conductance
$\mathrm{K}^{+}$channels, current transitions to the second channel level were often too short to provide a discrete peak on the amplitude histogram. In patches containing more than three low conductance $\mathrm{K}^{+}$channels, a combination of low unitary currents, noise, and brief transitions to the upper current levels usually prevented the generation of current amplitude histograms with sharply defined peaks.

Results are expressed as mean (SEM). Statistical analyses were performed using Student's $t$ test for paired data, where $\mathrm{p}<0.05$ was considered significant.

\section{Results}

\section{Low conductance $\mathrm{K}^{+}$channel}

Basic properties and $\mathrm{Ca}^{2+}$ dependence - we have previously described a $\mathrm{Ba}^{2+}$ blockable, $\mathrm{K}^{+}$selective channel in most cell attached and inside-out basolateral membrane patches of human colonic crypt cells. This channel has a conductance of $23 \mathrm{pS}$, is activated by $0.1 \mathrm{mM}$ carbachol in the cell attached configuration, and in the excised inside-out configuration is highly sensitive to changes in $\mathrm{Ca}^{2+}$ concentration within the micromolar range. ${ }^{6}$ Additional experiments in this study confirmed the high frequency $(>75 \%)$ with which this channel is seen in cell attached and inside-out patches, and the presence of two to six channels per patch.

Effects of blockers - addition of $1 \mathrm{mM}$ quinidine to the bath (that is, to the cytosolic side of the excised membrane patch) inhibited channel activity in seven of seven patches (Fig 1A), single channel open probability $\left(\mathrm{p}_{\mathrm{o}}\right)$ decreasing from $0.218(0.039)$ to 0.045 $(0.024) \quad(p<0.002)$. One $\mathrm{mM}$ DPC also blocked channel activity in five of five patches (Fig 1B), $p_{o}$ decreasing from $0.418(0.081)$ to $0.100(0.039)(p<0.025)$. As shown in Fig 1 ,

A

Basal

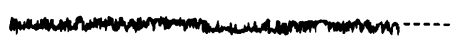

+Quinidine

Wash

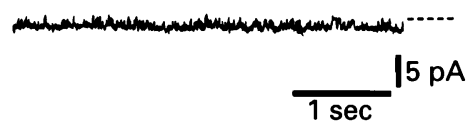

B

Basal

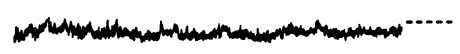

$+\mathrm{DPC}$

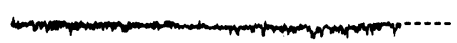

Wash

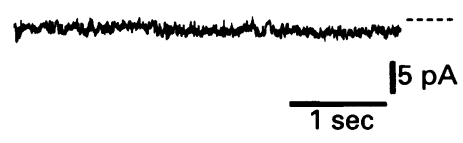

Figure 1: Blockade of low conductance $K^{+}$channels by 1 $m M$ quinidine $(A)$ and $1 m M D P C(B)$ in inside-out basolateral membrane patches of human colonic crypt cells $\left(V_{\text {com }}=-40 \mathrm{mV}\right)$, with restoration of channel activity when the blockers were washed out of the bath. In this and the other Figures, dashed lines show zero current levels, and downward current deflections show $K^{+}$flow from pipette (KCl solution) to bath ( $\mathrm{NaCl}$ solution). 


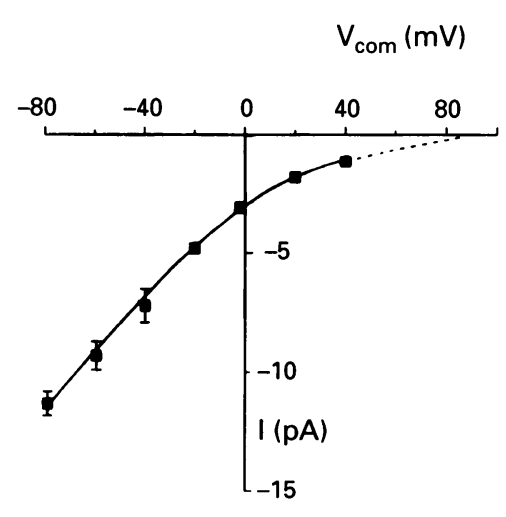

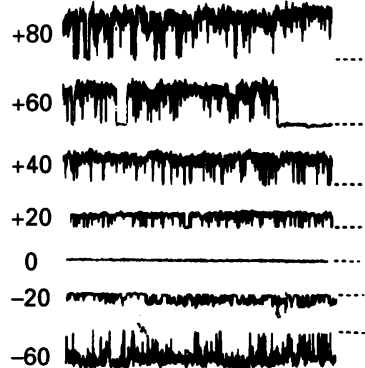

$$
\overline{1 \mathrm{sec}}^{15 \mathrm{pA}}
$$

Figure 2: Current-voltage relations of the high conductance $K^{+}$channel in inside-out basolateral membrane patch of human colonic crypt cell. In ( $A)$, data are derived from eight patches (KCl solution in pipette, NaCl solution in bath). Computer generated data fit and reversal potential $(84(0 \cdot 3) \mathrm{mV})$ obtained using the GHK current and voltage equations. Correlation coefficient ( $\mathrm{r}$ ) of the fit of the mean data was 0.9959. (B) shows representative recordings from an inside-out patch at different holding potentials (referenced to pipette) when bathed in symmetrical KCl solutions, and (C) summarises the current-voltage relations using data from five patches studied under these conditions.

channel activity was restored when quinidine and DPC were washed out of the bath. In contrast, $\mathrm{p}_{\mathrm{o}}$ was similar before and after the addition of $20 \mathrm{mM}$ TEA $(0 \cdot 231(0.018)$ and $0 \cdot 211(0 \cdot 016)$ respectively, $\mathrm{n}=5)$.

\section{High conductance $K^{+}$channel}

Basic properties - high conductance $\mathrm{K}^{+}$ channels (usually one or two per patch) were seen in 28 of $111(25 \%)$ cell attached patches. Current-voltage relations were linear in the cell attached configuration, and the single channel conductance and reversal potential were 117 (10) $\mathrm{pS}$ and 36 (7) $\mathrm{mV}$ respectively $(\mathrm{n}=7)$. Figure 2A shows the curvilinear current-voltage relation based on data from eight insideout patches ( $\mathrm{KCl}$ solution in pipette, $\mathrm{NaCl}$ solution in bath). Under these conditions, single channel conductance at $-40 \mathrm{mV}$ was 91 (5) pS. The best fit values of the reversal potential and $\mathrm{K}^{+}: \mathrm{Na}^{+}$permeability ratio (calculated by computer fitting the data to the Goldman-Hodgkin-Katz voltage and current equations ${ }^{1314}$ using the Simplex algorithm) were $84(0.3) \mathrm{mV}$ and 195 (14): 1 respectively. Pronounced voltage dependency of the channel was seen in $50 \%$ of patches, $p_{o}$ increasing with depolarisation. Figure $2 \mathrm{~B}$ shows representative current recordings from an inside-out patch bathed in symmetrical $\mathrm{KCl}$ solutions. The linear current-voltage relation derived from this and four other inside-out patches studied under similar conditions is shown in Fig $2 \mathrm{C}$, and indicates a single channel conductance of 138 (13) pS.

Effects of blockers - addition of $5 \mathrm{mM} \mathrm{Ba}^{2+}$ inhibited channel activity in four of four patches (Fig 3A), $p_{0}$ decreasing from $0 \cdot 169$ $(0.050)$ to $0.018(0.016)(p<0.05) .1 \mathrm{mM}$ quinidine reduced channel activity in four of four patches (Fig 3B), $p_{0}$ decreasing from $0.334(0.089)$ to $0.009(0.009) \quad(\mathrm{p}<0.05)$. Twenty $\mathrm{mM}$ TEA also had a considerable inhibitory effect in four of four patches (Fig $3 C)$, decreasing $\mathrm{p}_{\mathrm{o}}$ from $0.485(0.136)$ to $0.021(0.012)(p<0.05)$. As shown in Fig 3, channel blockade by $\mathrm{Ba}^{2+}$, quinidine, and
TEA was fully reversible. In contrast, $1 \mathrm{mM}$ DPC had no consistent effect on $p_{0}$ in five patches $(0.359(0.095)$ versus $0.288(0.064))$. $\mathrm{Ca}^{2+}$ dependence - removal of bath $\mathrm{Ca}^{2+}$ (in the presence of $2 \mathrm{mM}$ EGTA) considerably inhibited high conductance $\mathrm{K}^{+}$channel activity in four of four inside-out patches (Fig 4), $\mathrm{p}_{\mathrm{o}}$ decreasing from $0.337(0.091)$ to $0.054(0.043)$ $(p<0.05)$. The addition of $0.1 \mathrm{mM}$ carbachol (a $\mathrm{Ca}^{2+}$-mediated muscarinic agonist), however, had no effect on low basal levels of high conductance $\mathrm{K}^{+}$channel activity seen in four of four cell attached patches (data not shown).

$A$

Basal

$+\mathrm{Ba}^{2+}$

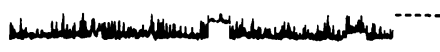

Wash

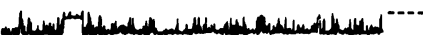

B

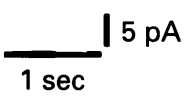

Basal

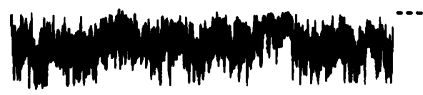

+Quinidine

Wash

C

$5 \mathrm{pA}$

Basal

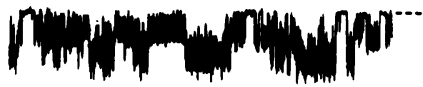

+ TEA

Wash

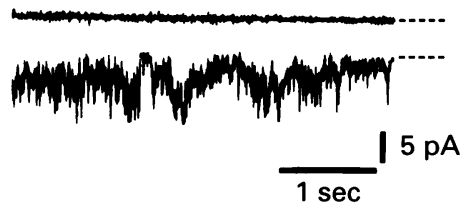

Figure 3: Blockade of high conductance $K^{+}$channels by 5 $m M B a^{2+}(A), 1 m M$ quinidine $(B)$, and $20 m M T E A$ (C) in inside-out basolateral membrane patches of human colonic crypt cells $\left(V_{\text {com }}=0 \mathrm{mV}\right.$ in $A$, and $-60 \mathrm{mV}$ in $B$ and $C)$, with restoration of channel activity when the blockers were washed out of the bath. 


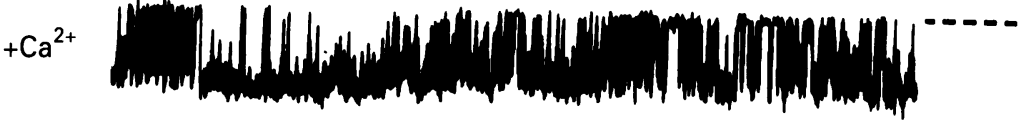

+EGTA P

$+\mathrm{Ca}^{2+}$

$5 \mathrm{pA}$

$1 \mathrm{sec}$

Figure 4: Sensitivity of high conductance $\mathrm{K}^{+}$channel to $\mathrm{Ca}^{2+}$ in inside-out basolateral membrane patch of human colonic crypt cell. Upper recording obtained with $1 \cdot 2 \mathrm{mM} \mathrm{Ca} \mathrm{a}^{2+}$ in bath and pipette $\left(V_{\text {com }}=-40 \mathrm{mV}\right)$. Middle recording obtained with $0 \mathrm{mM} \mathrm{Ca} \mathrm{Ca}^{2+}$ and $2 \mathrm{mM} E G T A$ in the bath. Lower recording shows return of channel activity when $1.2 \mathrm{mM}$ $\mathrm{Ca} \mathrm{a}^{2+}$ added to bath. contained clusters of low conductance $\mathrm{K}^{+}$ channels, which were blocked from the cytosolic side of the membrane by quinidine and DPC, but not by TEA. In contrast, a significant minority $(25 \%)$ of patches contained one or two high conductance $(138 \mathrm{pS}) \mathrm{K}^{+}$ channels, which sometimes coexisted with low conductance $\mathrm{K}^{+}$channels. High conductance $\mathrm{K}^{+}$channels were blocked by $\mathrm{Ba}^{2+}$, quinidine, and TEA, but not by DPC. They were also inhibited by removing $\mathrm{Ca}^{2+}$ from the bath solution, as reported for the low conductance $\mathrm{K}^{+}$channel. ${ }^{6}$ In view of the fact that both types of $\mathrm{K}^{+}$channel are $\mathrm{Ca}^{2+}$ sensitive in inside-out patches, it is unclear why carbachol failed to stimulate high conductance $\mathrm{K}^{+}$channels in cell attached patches. However, this may reflect different $\mathrm{Ca}^{2+}$ sensitivities of high and low conductance $\mathrm{K}^{+}$channels in the intact cell, as the addition of $0 \cdot 1 \mathrm{mM}$ carbachol stimulates a small, transient increase in free cytosolic $\mathrm{Ca}^{2+}$ concentration (about $40 \mathrm{nM}$ ) in $\mathrm{T}_{84}$ cells, ${ }^{4}$ and other studies have shown that high conductance $\mathrm{K}^{+}$channels require greater concentrations of free $\mathrm{Ca}^{2+}$ for activation than low conductance $\mathrm{K}^{+}$channels. ${ }^{18}$

Different populations of basolateral $\mathrm{K}^{+}$ channel have been identified in intestinal crypts in several mammalian and amphibian species. For example, the basolateral membrane of rat duodenal crypts contains 84-99 $\mathrm{pS} \mathrm{K}{ }^{+}$channels that are cAMP sensitive, $\mathrm{Ca}^{2+}$ insensitive, and blocked by $\mathrm{Ba}^{2+}$ and TEA; and 19-28 pS $\mathrm{K}^{+}$channels that are both cAMP and $\mathrm{Ca}^{2+}$ sensitive, and blocked by TEA but not $\mathrm{Ba}^{2+} .19$ Three types of $\mathrm{K}^{+}$conductance have been identified in the basolateral membrane of rat distal colonic crypts: clusters of $27 \mathrm{pS}$ non-selective cation channels, which may play a part in $\mathrm{K}^{+}$(rather than $\mathrm{Cl}^{-}$) secretion $^{20}$; frequently observed $12 \mathrm{pS} \mathrm{K}^{+}$ channels that are $\mathrm{Ca}^{2+}$ sensitive, blocked by $\mathrm{Ba}^{2+}$ and TEA, and which may participate in maintaining the cell membrane resting potential $^{21}$; and rare $187 \mathrm{pS} \mathrm{K}^{+}$channels that are also $\mathrm{Ca}^{2+}$ sensitive and blocked by $\mathrm{Ba}^{2+} .{ }^{21}$ Basolateral membranes of crypt cells in rabbit distal colon contain 90-220 pS $\mathrm{K}^{+}$channels that are $\mathrm{Ca}^{2+}$ and cAMP activated, and blocked by $\mathrm{Ba}^{2+}$ and TEA. ${ }^{22}$ Three distinct populations of $\mathrm{Ca}^{2+}$ sensitive channel seem to constitute the basolateral $\mathrm{K}^{+}$conductance in turtle colon epithelial cells: $30 \mathrm{pS}$ non-selective cation channels seen in most inside-out patches, which are blocked by quinidine and DPC but not by $\mathrm{Ba}^{2+} ; 35 \mathrm{pS}$ inward rectifying $\mathrm{K}^{+}$channels seen in $25 \%$ of patches, which are blocked by quinidine, $\mathrm{Ba}^{2+}$ and DPC; and infrequent $188 \mathrm{pS} \mathrm{K}^{+}$channels, blocked by quinidine and $\mathrm{Ba}^{2+}$ but not by DPC. ${ }^{12}$ The two populations of basolateral $\mathrm{K}^{+}$channel (23 pS and $138 \mathrm{pS}$ ) that we have identified in human colonic crypts resemble most closely the $35 \mathrm{pS}$ and $188 \mathrm{pS} \mathrm{K} \mathrm{K}^{+}$channels present in turtle colon. However, it is clear that no cross species generalisations can be made about the properties and possible physiological roles of basolateral $\mathrm{K}^{+}$channels in intestinal epithelia. From the point of view of ion transport function in the human colon, this study shows that erobable that the $\mathrm{K}^{+}$channel identified in cells in the middle third of the crypts represent basolateral $\mathrm{K}^{+}$channels in columnar (ion transporting) epithelial cells, which account for about $75 \%$ of the crypt cell mass. ${ }^{1617}$ We found a large proportion $(>75 \%)$ of basolateral membrane patches 
the two types of basolateral $\mathrm{K}^{+}$channel can be easily identified by their different unitary conductances and their different sensitivities to TEA and DPC.

Sensitivities of the two $\mathrm{K}^{+}$channel populations to different blockers may prove useful in studying their relative contributions to basolateral $\mathrm{K}^{+}$efflux in the resting and secretory states, and therefore to their roles in $\mathrm{Cl}^{-}$secretion stimulated by $\mathrm{Ca}^{2+}$ mediated agonists. Studies in $\mathrm{T}_{84}$ and HT29-clone 19A colonic epithelial cell lines have shown that basolateral $\mathrm{K}^{+}$efflux stimulated by $\mathrm{Ca}^{2+}$ mediated agonists (assessed using ${ }^{86} \mathrm{Rb}$ as a marker for $\mathrm{K}^{+}$) is blocked by $\mathrm{Ba}^{2+}$ but not by TEA. ${ }^{23}$ In contrast, in the HT29 parent cell line, $\mathrm{Ca}^{2+}$ stimulated $\mathrm{K}^{+}$efflux is blocked by both $\mathrm{Ba}^{2+}$ and TEA. ${ }^{24}$ Microphotometric studies suggest that stimulation of the basolateral $\mathrm{K}^{+}$conductance in the HT29 parent cell line requires comparatively higher intracellular concentrations of free $\mathrm{Ca}^{2+}$ (to $>800 \mathrm{nM}$ ), ${ }^{25}$ whereas basolateral $\mathrm{K}^{+}$efflux in the HT29-clone 19A cell line is stimulated by a transient rise in intracellular free $\mathrm{Ca}^{2+}$ to about $200 \mathrm{nM}{ }^{23}$ It therefore seems feasible that native crypt cells possess two different $\mathrm{Ca}^{2+}$ dependent basolateral $\mathrm{K}^{+}$ efflux pathways. One $\mathrm{K}^{+}$efflux pathway consists of low conductance $\mathrm{K}^{+}$channels that are highly $\mathrm{Ca}^{2+}$ sensitive, not blocked by TEA, and have been implicated in maintaining a favourable gradient for $\mathrm{Cl}^{-}$secretion. ${ }^{6}$ The other pathway consists of high conductance $\mathrm{K}^{+}$channels that are less $\mathrm{Ca}^{2+}$ sensitive and blocked by TEA. Their precise role remains unclear, but they may participate in volume regulation.

This study was supported by the Sir Jules Thorn Charitable Trust.

1 Chang EB, Rao MC. Intestinal water and electrolyte transport: mechanisms of physiological and adaptive responses. In: Johnson LR, ed. Physiology of the gastrointestinal tract. 3rd ed. New York: Raven Press, 1994: 2027-81.

2 McRoberts JA, Beuerlein G, Dharmsathaphorn K. Cyclic AMP and $\mathrm{Ca}^{++}$activated $\mathrm{K}^{+}$transport in a human colonic epithelial cell line. 7 Biol Chem 1985; 260: 14163-72.

3 Cartwright CA, McRoberts JA, Mandel KG, Dharmsathaphorn $\mathrm{K}$. Synergistic action of cyclic AMP and calcium-mediated chloride secretion in a colonic epithelial cell line. F Clin Invest 1985; 76: 1837-42.
4 Dharmsathaphorn K, Pandol SJ. Mechanism of chloride secretion induced by carbachol in a colonic epithelial cell line. $\mathcal{f}$ Clin Invest 1986; 77: 348-54.

5 Barrett KE. Chloride secretion by the colonic epithelial cell line $\mathrm{T}_{84}$ : mechanisms and regulation. Advances in Comparative and Environmental Physiology 1993; 16: 215-35. 6 Sandle GI, McNicholas CM, Lomax RB. Potassium channels in colonic crypts. Lancet 1994; 343: $23-5$.

7 Hamill OP, Marty A, Neher E, Sakmann B, Sigworth FJ. Improved patch clamp techniques for high-resolution cur-
rent recording from cells and cell-free membrane patches. Pflugers Arch 1981; 391: 85-100.

8 Greger R, Schlatter E, Gögelein H. Chloride channels in the luminal membrane of the rectal gland of the dogfish (Squalus acanthias): properties of the larger conductance (Squalus acanthias): properties of the larger
channel. Pflugers Arch 1987; 409: 114-21.

9 Singh AK, Afink GB, Venglarik CJ, Wang R, Bridges RJ. Colonic Cl channel blockade by three classes of compounds. Am f Physiol 1991; 260: C51-63.

10 Gögelein H, Pfannmüller B. The nonselective cation channel in the basolateral membrane of rat exocrine pancreas. Inhibition by $3^{\prime}, 5$-dichlorodiphenylamine-2carboxylic acid and activation by stilbene disulfonates. Pflugers Arch 1989; 413: 287-98.

11 Gögelein H, Greger R. A voltage dependent ionic channel in the basolateral membrane of late proximal tubules of rabbit kidney. Pflugers Arch 1986; 407: S142-8.

12 Richards NW, Dawson DC. Selective block of specific $\mathrm{K}^{+}$conducting channels by diphenylamine-2-carboxylate in conducting channels by diphenylamine-2-carboxylate in

13 Goldman DE. Potential, impedance and rectification in membranes. I Gen Physiol 1943; 27: 37-60.

14 Hodgkin AL, Katz B. The effect of sodium on the electrical activity of the giant axon of the squid. $\mathcal{F}$ Physiol 1949; 108: 37-77.

15 Weymer A, Huott P, Liu W, McRoberts JA, Dharmsathaphorn $\mathrm{K}$. Chloride secretory mechanism induced by prostaglandin $\mathrm{E}_{1}$ in a colonic epithelial cell line. $\mathcal{F}$ Clin Invest 1985; 76: 1828-36.

16 Arai T, Kino I. Morphometrical and cell kinetic studies of normal human colorectal mucosa: comparison between the proximal and the distal large intestine. Acta Pathol fpn 1989; 39: 725-30.

17 Bjerknes $M$, Cheng $H$. Methods for the isolation of intact epithelium from the mouse intestine. Anat Rec 1981; 199: epithelium

18 Pallotta BS, Blatz AL, Magleby KL. Recording from calcium-activated potassium channels. Meth Enzymol 1992; 207: 194-207.

19 McNicholas CM, Fraser G, Sandle GI. Properties and regulation of basolateral $\mathrm{K}^{+}$channels in rat duodenal crypts. F Physiol 1994; 477: 381-92.

20 Siemer C, Gögelein H. Activation of nonselective cation channels in the basolateral membrane of rat distal colon crypt cell by prostaglandin $\mathrm{E}_{2}$. Pflugers Arch 1992; 420: crypt cell

21 Burckhardt B-C, Gögelein $\mathrm{H}$. Small and maxi $\mathrm{K}^{+}$channels in the basolateral membrane of isolated crypts from rat in the basolateral membrane of isolated crypts from rat distal colon: single channel and sto
Pflugers Arch 1992; 420: 54-60.

22 Loo DD, Kaunitz JD. $\mathrm{Ca}^{2+}$ and cAMP activate $\mathrm{K}^{+}$channels in the basolateral membrane of crypt cells isolated from rabbit distal colon. $\mathcal{F}$ Memb Biol 1989; 110: 19-28.

23 Fogg KE, Higgs NB, Warhurst G. Involvement of calmodulin in $\mathrm{Ca}^{2+}$-activated $\mathrm{K}^{+}$efflux in human colonic cell line, HT29-19A. Biochim Biophys Acta 1994; 1221: 185-92.

24 Wu H, Franklin CC, Kim HD, Turner JT. Regulation of calcium-activated potassium efflux by neurotensin and other agents in HT-29 cells. Am f Physiol 1991; 260: C35-42

25 Amar S, Kitabgi P, Vincent J-P. Activation of phosphatidylinositol turnover by neurotensin receptors in the human colon adenocarcinoma cell line HT29. FEBS Lett 1986; 201: 31-6. 